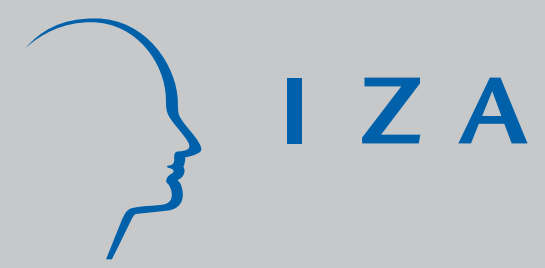

IZA DP No. 5775

Social Contacts and the Economic Performance of Immigrants: A Panel Study of Immigrants in Germany

Agnieszka Kanas

Barry R. Chiswick

Tanja van der Lippe

Frank van Tubergen

June 2011 


\title{
Social Contacts and the Economic Performance of Immigrants: A Panel Study of Immigrants in Germany
}

\author{
Agnieszka Kanas \\ Utrecht University \\ Barry R. Chiswick \\ George Washington University and IZA \\ Tanja van der Lippe \\ Utrecht University \\ Frank van Tubergen \\ Utrecht University
}

\author{
Discussion Paper No. 5775 \\ June 2011
}

IZA

P.O. Box 7240

53072 Bonn

Germany

Phone: +49-228-3894-0

Fax: +49-228-3894-180

E-mail: iza@iza.org

\begin{abstract}
Any opinions expressed here are those of the author(s) and not those of IZA. Research published in this series may include views on policy, but the institute itself takes no institutional policy positions.

The Institute for the Study of Labor (IZA) in Bonn is a local and virtual international research center and a place of communication between science, politics and business. IZA is an independent nonprofit organization supported by Deutsche Post Foundation. The center is associated with the University of Bonn and offers a stimulating research environment through its international network, workshops and conferences, data service, project support, research visits and doctoral program. IZA engages in (i) original and internationally competitive research in all fields of labor economics, (ii) development of policy concepts, and (iii) dissemination of research results and concepts to the interested public.
\end{abstract}

IZA Discussion Papers often represent preliminary work and are circulated to encourage discussion. Citation of such a paper should account for its provisional character. A revised version may be available directly from the author. 


\section{ABSTRACT}

\section{Social Contacts and the Economic Performance of Immigrants: A Panel Study of Immigrants in Germany ${ }^{*}$}

Using data from the German Socio-Economic Panel, we examined the impact of social contacts on immigrant occupational status and income. In addition to general social contacts, we also analyzed the effects of bonding (i.e., co-ethnic) and bridging (i.e., interethnic) ties on economic outcomes. Results show that general social contacts have a positive effect on the occupational status and, in particular, annual income of immigrants. We also find that bridging ties with Germans lead to higher occupational status, but not to increased income. These effects remain visible even when social contacts are measured (at least) one year prior to the economic outcomes, as well as when earlier investments in German human capital are considered. Finally, we show that co-ethnic concentration in the region of residence weakly affects economic returns to German language proficiency and schooling.

JEL Classification: F22, J61, Z13

Keywords: immigrants, social contacts, occupational status, income, panel data

Corresponding author:

Agnieszka Kanas

Department of Sociology

Utrecht University

Heidelberglaan 2

3584 CS Utrecht

The Netherlands

E-mail: a.m.kanas@uu.nl

\footnotetext{
* This paper is forthcoming in the International Migration Review. Earlier versions were presented at the seminar at the Department of Economics, University of Illinois at Chicago, USA, February 2009; International Workshop: 'Matching Context and Capacity: the Economic Integration of Immigrants,' Florence, Italy, June 2009; Trinity Immigration Initiative seminar, Trinity College Dublin, Ireland, February 2010.
} 


\section{Introduction}

In Western countries, immigrants tend to have lower occupational statuses and smaller incomes than native workers (OECD 2008). A well-known explanation for the economic disadvantage faced by immigrants concentrates on human capital. This theory stipulates that immigrants are less skilled and less productive than are natives. Because many immigrants come from less-developed countries, they are often less educated than the native-born population. Furthermore, immigrants cannot rely on their human capital as natives do, because the skills they gained in their countries of origin may be of lower quality, and are often more difficult to transfer. In addition, employers are uncertain about these specific skills (e.g., Chiswick 1978; Duleep and Regets 1997, 1999; Friedberg 2000). As the length of stay in the host country increases, however immigrants tend to improve their economic outcomes. An explanation for this economic mobility is that immigrants acquire the hostcountry language and skills that allow them to compete more effectively in the host-country labor market. There is ample support in the literature for the notion that immigrants who acquire proficiency in the host-country language significantly improve their economic opportunities (Chiswick and Miller 1995, 2002; Dustmann and Van Soest 2002; Shields and Wheatley Price 2002). Similarly, research has shown that acquiring host-country credentials and labor market experience facilitates the economic integration of immigrants (e.g., Bratsberg and Ragan 2002; Friedberg 2000; Kanas and Van Tubergen 2009).

Another important explanation for immigrants’ economic disadvantage focuses on social capital. Upon arrival in the host country, immigrants benefit from relationships with co-ethnic family and friends. These contacts provide them with knowledge, information and other essential skills, including how to search for a job and how to behave on the job. These skills, in turn, facilitate the immigrant's adjustment to the labor market. Several studies have shown 
that having co-ethnic family and friends in the host-country facilitates the economic integration of immigrants, in particular by providing assistance in finding a job and higher earnings (Aguilera 2002, 2003, 2005; Aguilera and Massey 2003; Amuedo-Dorantes and Mundra 2008, Hagan 1998; Nee et al. 1994; Sanders et al. 2002).

An influential hypothesis in the scholarly literature on social capital states that contacts with natives are even more beneficial for immigrant economic outcomes than co-ethnic contacts (Hagan 1998; Putnam 2000). Relationships with natives can provide access to the host society by facilitating social and cultural adaptation and providing broader job choices (Drever and Hoffmeister 2008; Kazemipur 2006). In this way, contacts with natives are a form of bridging social capital that is crucial for providing access to external resources and for the diffusion of information, whereas contacts with co-ethnics are a form of bonding social capital that is most useful for strengthening solidarity and reciprocal relationships (Portes and Sensenbrenner 1993; Putnam 2000).

Although several studies have examined the relationship between bridging social contacts and immigrant economic outcomes (Drever and Hoffmeister 2008; Kalter 2006; Kanas and Van Tubergen 2009; Kanas et al. 2009; Kazemipur 2006; Lancee 2010), most prior research has relied on cross-sectional data, which makes it difficult to infer the causal effects of bridging social contacts. In these studies, a positive correlation between immigrants' social contacts and economic outcomes is interpreted as evidence of the effect of social contacts. However, because higher occupational status and/or income provide people with more resources to meet and interact with others, the positive correlation between social contacts and immigrants' economic outcomes may reflect reverse causality - the tendency of people with better economic outcomes to have more friends (Lin 2000).

The positive correlation between social contacts and economic outcomes for immigrants may also be spurious, merely reflecting the fact that people with similar backgrounds tend to 
associate with one another (McPherson, Smith-Lovin, and Cook 2001; Mouw 2003, 2006). The problem of social homophily has been recently addressed in two studies on immigrants in Germany (Kalter 2006; Kanas et al. 2011). Kanas et al. (2011) estimated a fixed-effects model and found that even after taking into account a possible bias caused by social homophily, immigrants who have social contacts with Germans are more likely to be employed as compared to those without such contacts. Based also on the fixed effects model, Kalter (2006) showed that having German friends increases the occupational status of second-generation Turkish immigrants.

This paper attempts to build on this scholarship by studying the occupational status and annual income of immigrants to Germany. It contributes to the literature in three ways. First, we focus not only on the impact of social contacts with co-ethnics but also on social contacts with natives. There is a longstanding tradition of research on the impact of ethnic enclaves on immigrant economic incorporation (e.g., Chiswick and Miller 2002, 2005; Hagan 1998; Kogan and Kalter 2006; Portes and Jensen 1989; Sanders and Nee 1987). However, mostly due to the limitations of the available data, few studies have analyzed the impact of contacts with natives on the economic outcomes of immigrants.

Our second contribution is that we use longitudinal data that enables us to test the causal effect of social contacts more rigorously. The German Socio-Economic Panel (GSOEP) is a comprehensive dataset that offers information on immigrant social contacts with family, friends, and neighbors, contacts with Germans, volunteering, and immigrants' economic performance over a twenty-year period. We also have additional information about the percentage of co-ethnics in the immigrants' region of residence from the German Microcensus. We examine the influence of social contacts on immigrants' occupational status and annual income. 
Occupational status and income may be viewed as two (imperfect) measures of the same immeasurable variable of interest, labor market outcome. Although economists have often expressed concern over immigrants' earnings, and sociologists have mused over the occupational status of immigrants, the extant literature rarely addresses both outcomes conjointly. By studying both occupational status and income simultaneously, we provide more insight into the role of social contacts in immigrants' economic progress, which occurs not only among occupations but also within them. Although the occupational status and income are estimated separately, it should be noted that occupation can be also considered as an intervening variable between education/language proficiency and income. That is, education and language skills can have both direct and indirect effects on immigrants' income, where indirect effects operate via occupational attainment. There are several reasons why we do not include the occupational status in the income equation, however. First, in the literature occupation is typically viewed as an aggregated variant of the income variable, and so using it as an independent variable in the income equation is considered illegitimate (Mincer (1979) as cited in Sloane (1985, p. 125). Second, the assumption that people get their occupational status first and then earn the income may be, in our view, problematic as people are likely to make decisions about the two things simultaneously. Third, what is even more important reason for us is that the occupational status is only observed among employed immigrants, and so it cannot be included in the selection equation (i.e., whether an immigrant works or not) of our Heckman model.

Third, we contribute to the literature by studying interactions between social contacts and origin- and host-country human capital. More specifically, we ask whether ethnic concentration in a region of residence affects the economic returns to origin- and hostcountry human capital. Assuming that co-ethnic regional concentration increases the transferability of origin-country specific human capital and reduces the uncertainty of 
employers towards origin-country skills, the lack of host-country specific human capital can be less important in regions with high concentrations of co-ethnics than it would be in regions with fewer co-ethnics (Chiswick and Miller 2002, 2005; Kanas and Van Tubergen 2009). This would suggest that immigrants living among co-ethnics will benefit more from their origin-country human capital, but, at the same time, they will receive comparatively lower returns to host-country human capital than do those living in regions with fewer co-ethnics (Chiswick and Miller 2002, 2005).

\section{Theory and hypotheses}

\section{Social contacts}

According to social capital theory, social contacts facilitate economic opportunities because they make accessible to people the resources of others, most notably knowledge, information and influence (i.e., recommendation letters) (Boxman, De Graaf, and Flap 1991; Granovetter 1973; Ioannides and Loury 2004; Lin 1999; Mouw 2002; Portes and Sensenbrenner 1993). Immigrants benefit from their social contacts by obtaining information specific to the host country and assistance in the labor market, including vital facts and advice about where to look for a job, what the available jobs are, how to present themselves to employers, and how to behave on the job (Aguilera and Massey 2003; Fernandez-Kelly 1995).

The most immediate sources of social contacts for immigrants are co-ethnic family and friends already living in the host-country. Immigrants also acquire their social contacts through leisure activities, such as volunteer work, and from neighborhood and job acquaintances (Aguilera and Massey 2003; Martinovic et al. 2009). Living among many coethnics is not only important for immigrants because it facilitates access to lower cost ethnic goods and services, including ethnic foods, clothing and co-ethnic contacts, but also 
facilitates their economic outcomes by allowing communication in the immigrant's native language and providing assistance in the host-country labor market (Bauer et al. 2005; Chiswick and Miller 2002, 2005). This leads us to hypothesize that the more social contacts immigrants have, the higher the occupational status and annual income of immigrants (H1).

The extant literature suggests that the quality of the resources of the contact person affects the quality of the job that is found via this person (e.g., De Graaf and Flap 1988; Lin 1999). It follows that people who obtained a job through a person with a higher occupational status find higher status jobs than those who were helped by a person with lower occupational status. It can be argued that at the host country labor market, knowledge and information provided by natives may be superior to those provided by co-ethnics. Natives are better informed about specific job openings, they know more about how to find jobs, and they know more about how to present themselves to employers than do non-natives. One reason for this difference in resources is that natives have more exposure to the domestic labor market through their own experiences and those of their parents than do immigrants. Another reason is that typically natives are less often unemployed, are more highly educated and have more prestigious jobs than immigrants (e.g., OECD 2008).

Furthermore, several studies in the literature on the native-born population suggested that social contacts whose social networks extend far beyond one's own network are more valuable in the labor market than social contacts whose social network overlaps with one's own network (Burt 2000; Granovetter 1973; Lin, Ensel and Vaughn 1981; Putnam 2000). For example, Burt (2000) suggested that being connected to different social networks, which are otherwise disconnected by structural holes, provides advantages in access to different sources of information, which are more additive than overlapping. A similar conclusion was reached by Putnam (2000), who suggested that although bonding social capital, which connects socially homogenous people by similarities in gender, ethnicity, and socio-economic status, is 
crucial for getting by, bridging social capital that links socially heterogeneous people is critical in getting ahead. Although these studies were not concerned with immigrants, they imply that contacts with natives, which reach outside an immigrant's own ethnic group, are more helpful for finding better jobs than are co-ethnic contacts.

In this context, some authors have argued that connections to co-ethnics might even hamper access to high status salary jobs. Wiley (1967) suggested that although co-ethnic enclaves protect immigrants by offering more secure job opportunities, they also reduce the possibilities to meet and interact with natives, thereby isolating immigrants from better job opportunities in the mainstream economy. Concurring with this argument, Martinovic et al. (2009) showed that in the Netherlands, immigrants who resided in heavily co-ethnic areas developed significantly fewer contacts with Dutch natives as compared to immigrants who lived in the regions with fewer immigrants. Because more lucrative jobs lie mainly outside the ethnic enclaves, relying solely on ethnic ties would lead immigrants to find jobs of lower prestige and earnings (Portes 1998; Sanders and Nee 1987). Based on the foregoing observations, we hypothesize that immigrants who have more contacts with natives have a higher occupational status and a higher annual income than those who have fewer contacts with natives (H2).

\section{Co-ethnic concentration and origin- and host-country human capital}

We also hypothesize about interactions between co-ethnic residential concentration and human capital. More specifically, we test whether living among many co-ethnics affects the economic returns to origin- and host-country human capital. It can be argued that immigrants who live in regions with many co-ethnics can benefit more from their origin-country skills than do immigrants who live in the regions with few co-ethnics (Bauer et al. 2005; Chiswick and Miller 2002, 2005). Specifically, co-ethnic concentration increases the transferability of 
origin-country skills by facilitating communication in the immigrant's native language and harnessing knowledge and experiences specific to a particular ethnic background (Chiswick and Miller 2005). Co-ethnic concentration can also reduce the uncertainty of employers by enabling employment with co-ethnic employers who are knowledgeable about origin-country specific credentials, or by influencing native employers to become more familiar with origincountry credentials (Kanas and Van Tubergen 2009). Based on these arguments, we hypothesize that the higher co-ethnic concentration in the region of residence, the higher the economic returns to origin-country human capital (H3).

By facilitating employment in occupations in which origin-country skills are more transferable and more highly valued by employers, co-ethnic residential concentration can also reduce the economic returns to host-country human capital. Specifically, by enabling immigrants to communicate in their native language, co-ethnic residential concentration reduces the cost of not speaking the destination language (Bauer et al. 2005). Similarly, by increasing the transferability of, and reducing the employers' uncertainty towards credentials acquired in the immigrant's country of origin, residing among many co-ethnics reduces the costs of not having destination educational credentials or training. In line with these arguments, Chiswick and Miller (2002) showed that immigrants to the United States who live in areas where many others speak their language, known as areas of high linguistic concentration, are not only less proficient in English, but also receive lower returns to their English language skills as compared to those who live outside areas of high linguistic concentration. These arguments lead us to our fourth hypothesis, that the higher the co-ethnic concentration in the region of residence, the lower the economic returns to host-country human capital (H4).

\section{Data and methods}


The data analyzed in this study are for employed foreign-born men age 20 to 60 years. ${ }^{1}$ The data are from the 1984-2004 German Socio-Economic Panel (GSOEP), a nationally representative longitudinal survey administrated by the German Economic Institute, DIW Berlin (see Haisken-DeNew and Frick 2005 for detailed information about the GSOEP survey). The key advantage of the GSOEP is that it provides longitudinal information on immigrants' social contacts, including contacts with natives, language skills, and pre- and post-migration education over a twenty-year period. Another advantage of the GSOEP is that several foreign groups, namely those of Turkish, Greek, Italian, Spanish, Portuguese and exYugoslavian origin, are over-sampled in the survey. ${ }^{2}$ The limitation of the data is that a majority of immigrants were interviewed for the first time only after they had spent a considerable amount of time in Germany. Because most of the investments in human and social contacts take place at the arrival to the host country, it could be that social contacts were more important for immigrants' occupational status and income in the first years after arrival than they are now after many years spent in Germany. ${ }^{3}$

For the purpose of this paper, we used sample B (immigrant population from Turkey, Greece, Yugoslavia, Spain and Italy - the so-called "guest workers") and sample D (immigrants who arrived in Germany after 1984 mainly from Eastern Europe-Aussiedlersand from other developing countries).

\section{Dependent and independent variables}

Occupational status: employed respondents were asked their occupation for their current job. Occupational status is measured in terms of the International Socio-Economic Index (ISEI) (Ganzeboom, De Graaf, and Treiman 1992). The ISEI scale measures the hierarchical position of the occupation. It is a set of weights assigned to occupations in such a way as to maximize the role of occupation as an intervening variable between education and income. 
The scale ranges from 16 (agricultural workers, hotel and restaurant cleaners) to 90 (judges). The mean occupational status in our sample of immigrants is 33 points, which is equivalent to sewers; wood treaters, cabinet-makers, etc. trades workers; and plumbers. An increase of one standard deviation in the average occupational status (ISEI score $=43$ ) would be equivalent to working in one of the following occupations: social work associated professionals; production clerks; and salespersons. A decrease of one standard deviation (ISEI score $=24$ ) would be equivalent to working in such occupations as: handpackers and other manufacturing laborers; semiskilled workers; bleaching, dyeing and cleaning-machine operators (Ganzeboom and Treiman 1996).

Annual income: respondents reported their annual individual income. This includes income from all employment including training, primary and secondary jobs, and selfemployment, plus income from bonuses, overtime, and profit-sharing. In all waves, the income variable is reported in Euros. In the analysis, the natural logarithm of annual income is used to account for the positive skewness of the annual income variable, the heteroscedasticity of income and to facilitate the interpretation of the coefficients. This is a standard procedure in the analysis of income and earnings.

We include measures of general social contact as well as measures of bridging and bonding social contact. As a measure of general social contact, we use two variables. Frequency of contacts: respondents were asked how frequently they spent time with their friends, relatives and neighbors. The possible answers were: never, occasionally, and often/regularly. Because categorical specification did not improve the model fit significantly, we treated frequency of social contacts as a continuous variable.

Volunteering activity: respondents were asked whether they volunteered for any clubs, associations or social services during the last year. The possible answers were: weekly, monthly, less frequently, and never. Only a few people volunteered at all during the last year; 
therefore, we recoded this variable into a dichotomous variable with a score 1 for those respondents who volunteered at least once during the last year.

As a measure of bridging social contacts, we include contacts with Germans. Respondents were asked whether they had made close German friends since they lived in Germany, whether in the last 12 months they had visited Germans in their homes, and whether in the last 12 months they received German visitors in their homes. The possible answers to all these questions were yes (equal to 1 ) and no (equal to 0). Answers to these questions are highly correlated, and we therefore combined them by adding up the scores on the three items and dividing them by three (Cronbach’s alpha 0.80).

As a measure of bonding versus bridging social contacts, we use two variables. Partner: respondents were asked whether they were married or cohabitating, and about the partner's country of birth. We constructed a variable with three categories: 1). single, 2). ethnic partner (if a partner was born outside Germany), 3). German partner (if a partner was born in Germany).

Ethnic concentration in the region of residence: measured by the percentage of co-ethnics (of the same ethnic group) in 1996 residing in nine federal states (Bundesländer, i.e., Schleswig-Holstein, Lower Saxony, Bremen, North Rhine-Westphalia, Hesse, RhinelandPalatinate, Baden-Württemberg, Saarland and Bavaria) and two German cities (Berlin and Hamburg) in West Germany where the respondents live (Microcensus Scientific Use File 2009). ${ }^{4}$ We assume that co-ethnic regional concentration increases the opportunities to meet and interact with co-ethnics, and at the same, it reduces the chances to make contacts with natives. The opportunities for contacts with co-ethnics and Germans could be measured more accurately at the labor market level than at the level of a federal state. Unfortunately, there is no information about respondents' labor market or neighborhood in the public use file of the GSOEP survey. 
Additional measures of bonding and bridging contacts, including their number, diversity and resources, would have been preferable. At the same time, however, there are few studies that have longitudinal information about immigrants' social contacts, and in particular about social contacts with natives.

We include several measures of human capital. Host-country human capital is measured by two indicators. Education in Germany: respondents were asked about the highest degree taken in secondary school as well as for completed vocational and post-secondary training. Respondents were also asked whether they received their education in Germany. Based on the highest level of obtained education in Germany, we constructed a variable measuring years of education in Germany (cf. Pischke 1992, for details see Appendix).

German language skills: respondents were asked how well they speak the German language. The possible answers were: do not speak German at all; speak German poorly; speak German fairly, speak German well; speak German very well. We treat German language skills as a continuous variable.

Human capital from the country of origin is measured directly by one indicator. Education abroad: the information on schooling in the country of origin was rather limited. The possible answers in the questionnaire were: less than compulsory, more than compulsory, and higher schooling. Information about training in the country of origin is more detailed: none, some instruction on-the-job, formal apprenticeship, vocational school, university and other. Based on the highest level of acquired education in the country of origin, we constructed a variable measuring years of education abroad (cf. Pischke 1992, see also Appendix). To understand how education abroad and education in Germany are measured, consider an example. An immigrant who first obtained vocational diploma in Turkey, and then attended a vocational school in Germany is assigned to have completed 10 years of education in Turkey and 12 years of education in Germany. 
We also provided measures for general human capital. Work experience: the survey provided a direct measure of work experience years from abroad and Germany. To control for the nonlinear relationship between work experience years and occupational status and income, we also included the quadratic form of work experience.

Several control variables were included in our model. Years since migration: measured by the total number of years in Germany. Weekly working hours: measured by the respondent's report of the average number of hours worked per week.

We controlled for the respondent's health based on previous research (i.e., Becker 2007), suggesting the importance of health status for individual productivity and so for individual economic outcomes. Doctor visits: respondents were asked how many times they went to the doctor in the last three months. Because surveys in 1985, 1986, 1987 and 1993 had asked the question for every specialist separately, we computed the total number of doctor visits during the last 3 months. We treated the doctor visit variable as a dichotomous variable with score 1 for those who visited a doctor at least once in the last three months.

Immigrant group: we distinguished between seven origin groups: 1). Turkish; 2). Greek; 3). ex-Yugoslavian; 4). Italian; 5). Spanish; 6). Eastern European; and 7). Third country immigrants. We also included a set of dichotomous variables for survey year to control for contextual factors such as employment opportunities, migration flows, and increases in means of the annual income due to inflation.

\section{Method}

We estimate the effect of social contacts on immigrants' occupational status and annual income. To take into account that the occupational status and income are only estimated for immigrants who work, we apply Heckman's (1979) sample selection model in Stata 11. Heckman's sample selection model produces regression weights and standard errors that are 
unbiased by the selection effects. One identifying variable is used in the selection equation: the presence of children in the household (i.e., none, one or two, more than two). The presence of children in the household is likely to influence adult male immigrants' participation in the labor force, but it is less important for their occupational status and income. Heckman's selection model produces the coefficient rho, which indicates a correlation of the error terms of the selection equation (i.e., whether or not one works) and the outcome equation (occupational status and annual income). Presence of children has a negative and significant effect in both selection equations, and the rho coefficient is highly significant in all models, suggesting that occupational status and annual income are indeed dependent on immigrants' choice to work. Therefore, we base our results on Heckman's sample selection model.

To account for the hierarchical structure of the data, i.e., the repeated observations of the same person over time (on average 7 years (waves)) and in community (a combination of an immigrant group and a region of living), we correct for clustering at a community level. A community is defined as a combination of an immigrant group and a region of residence, such as Turkish immigrants in Berlin. There are 60 communities in total in our sample. ${ }^{5}$ We use the cluster option in Stata 11 to estimate robust standard errors that adjust for intra-cluster (within individual and within community) correlations (Stata Library 2010) ${ }^{6}$ By doing this we correct the standard errors of the parameters for the dependence of the repeated observations of the same person over time and community (Froot 1989).

We further study the causal relationship between human capital, social contacts and the occupational status and annual income of immigrants by including in the models lagged measures of host-country human capital and social contacts. The main insight from the literature is that immigrants with more social contacts have better economic outcomes. However, it can be argued that a positive correlation between social contacts and immigrants' 
economic outcomes could also reflect the influence of economic outcomes on the frequency and composition of immigrant social contacts. For instance, higher status jobs may increase the opportunities to meet and socialize with natives. To reduce the possibility of reverse causality between social contacts and occupational status (annual income), social contact variables were measured to one year prior to the immigrant's current occupational status and annual income. ${ }^{7}$

A positive correlation between bridging social contacts and occupational status or income can be also spurious due to time-varying host-country human capital accumulation. Acquiring host-country human capital may facilitate immigrants' economic outcomes and social contacts with natives, not that contacts with Germans lead to higher economic outcomes. For example, immigrants who speak the German language and who have German educational credentials may be more likely to have higher occupational status and income and more German contacts than immigrants without these qualifications. We measured host-country human capital variables by two years and social contact variables by one year prior to the immigrants' current occupational status and income to determine whether a (positive) correlation between social contacts with Germans and immigrant economic outcomes is causal, or instead represents a spurious effect attributable to prior accumulation of hostcountry human capital. ${ }^{8}$

Table 1 presents descriptive statistics for the independent and dependent variables.

TABLE 1 ABOUT HERE 


\section{Results}

Table 2 and 3 present the results from Heckman's sample selection model predicting the effect of social contacts on immigrant occupational status (Table 2) and annual income (Table 3). Each table has three models. Model 1 includes only measures of social contacts and controls. Model 2 includes measures of social contacts, human capital and control variables, and Model 3 includes additional interaction effects between ethnic concentration in the area of residence and origin- and destination-country specific human capital. We meancentered the continuous variables of German education, education abroad, German language skills and ethnic concentration included in Model 3 because they are used to construct interaction terms, and centering reduces the possibility of multicollinearity (Aiken and West 1991). Also with centering, the estimated coefficients for the main effects usually refer to meaningful values rather than the meaningless score of zero on variables such as ethnic concentration, education and language skills. We compare the coefficients of social contacts from Model 1 with those of Model 2 to test whether the positive relationship between social contacts and immigrant occupational status and annual income could be spurious due to (previous) host-country human capital accumulation.

Finally, Table 4 presents the results for the occupational status and income using sheaf coefficients. The sheaf coefficient may be thought of as a latent variable that underlies several related measured indicators. It is constructed as a weighted linear sum of the measured indicators such that the latent variable optimally predicts the dependent variable (Buis 2009). We constructed three sheaf coefficients: "general social contacts” comprising of frequency of contacts and volunteering activity, "bridging contacts” comprising of three indicators of German contacts (i.e., having close German friends, being visited by Germans and visiting Germans) and German partner versus single/ethnic partner; and "host-country 
human capital” comprising of German education and German language skills. The advantage from using the sheaf coefficient instead of multiple indicators in the regression is that it addresses problems of multicollinearity (Whitt 1986; Yamaguchi 2002). Another advantage is that it enables us to compare the relative strength of influence of created latent variables, i.e., "general social contacts" versus "bridging social contacts”. That is, because each sheaf coefficient is standardized to a mean of 0 and a standard deviation of 1 , different sheaf coefficients are more easily compared.

\section{TABLES 2 and 3 ABOUT HERE}

\section{Social contacts}

We hypothesized that more general social contacts would enable immigrants to obtain higher occupational status and annual income (H1). We test this hypothesis by examining the effects of the frequency of social contacts, volunteering activity and having a co-ethnic or German partner, all measured prior to occupational status and income. The results partially confirm this hypothesis (Model 1, Table 2 and 3). Specifically, our results clearly show that volunteering in the previous year increases immigrants' occupational status by 1.39 status points (Model 1, Table 2). This is a small effect: an increase in 1.39 point does not lead to any substantial change in immigrant occupational status (the range of the ISEI scale in our sample is 16-88, with a standard deviation SD =9.6). We also find that having a German partner as compared to being single leads to a significant increase in the occupational status of immigrants (the coefficient for German partner as opposed to being single is: $b=3.70, \mathrm{p}=$ 0.05). Contrary to our expectation, however, we do not find that immigrants who have an ethnic partner have higher occupational status than those who are single, by a statistically 
insignificant - 0.59. Perhaps single immigrants interact more with Germans than immigrants who are married to an ethnic partner. Similarly, we do not find a significant positive effect of frequent contacts with friends, relatives and neighbors on immigrant occupational status.

Our results show that for each unit of increase in frequent contacts with friends, relatives and neighbors in the previous year immigrant annual income rises by 5 percent (Model 1, Table 3). Moreover, having a partner as compared to being single in the previous year leads to an increase in immigrants' annual income (the coefficient for an ethnic partner is 7.8 percent, for a German partner is 13.2 percent). We do not find that volunteering activity in the previous year leads to any increase in the annual income, however.

Thus, it appears that general social contacts have more of an effect on the annual income, but only a very small or no effect on the occupational status. This suggests that although immigrants benefit from having general social contact, which help them finding well-paid jobs, these are rarely jobs with higher occupational status (Drever and Hoffmeister 2008).

We also hypothesized that immigrants who have more contacts with Germans achieve higher occupational status and income (H2). In general, our results support this hypothesis. We find that immigrants with a German partner have a considerably higher occupational status - 4.29 status points higher and 5.5 percent greater annual income-than do immigrants with an ethnic partner (Model 1, Table 2 and 3). Similarly, we find evidence that having contacts with Germans in the previous year increases occupational status by 2.94 status points and raises annual income by 3.2 percent (at $p$.09) (Model 1, Table 2 and 3). Finally, our results show no significant relationship between a high co-ethnic residential concentration and immigrant occupational status and annual income. ${ }^{9}$ 
Social contacts and origin- and host-country human capital

A positive association between social contacts and immigrant occupational status and annual income could be spurious due to (previous) host-country human capital accumulation. To test this proposition, we compare Model 1, which only includes social contacts variables and control variables, with Model 2, which includes previous measures of host-country human capital. The model comparison shows that although the positive effect of contacts with Germans decreases by more than half $(b=2.94$, Model 1 , Table $2 ; b=1.10$, Model 2 , Table 2), it still has a direct effect on immigrant occupational status. Similarly, the strong positive effect on occupation from having a German partner versus an ethnic partner remains valid after controlling for host-country human capital $(b=4.29$, Model 1 , Table $2 ; b=2.61$, Model 2, Table 2).

Our results suggest that the positive effect of bridging social capital on annual income is spurious, owing in large part to earlier investments in host-country human capital (Model 2, Table 3). Specifically, the positive effect from having a German as opposed to ethnic partner becomes marginally significant $(p<0.09)$ after accounting for previous investments in hostcountry human capital (Model 2, Table 3). Similarly, the positive effect of having contacts with Germans becomes insignificant in the model with host-country human capital variables. Overall, we only find evidence for the direct positive effect of contacts with natives on immigrant occupational status. With respect to income, our results suggest that the significant effect of contacts with natives is spurious, stemming instead from host-country human capital accumulation.

We have further hypothesized that a higher co-ethnic concentration in the region of residence produces higher economic returns to origin-country human capital (H3). As a start, our results show that education abroad leads to an increase in the occupational status and annual income (Model 2, Tables 2 and 3). We also find that immigrants who obtained their 
education in Germany have higher occupational status and annual income as compared to those who did not acquire German education. ${ }^{10}$ Thus, investing in host-country credentials provides additional human capital that improves immigrant position at the host-country labor market. Furthermore, German language proficiency has a positive effect on occupational status and annual income. Our results also show that total number of years of work experience has a negative effect on occupational status but exerts a positive effect on annual income of immigrants. Although it is quite surprising that immigrants with more work experience have lower occupational status, the effect is relatively inconsequential. That is, the difference between having minimum (0) and maximum (47) years of work experience is approximately 3.9 occupation status points. Because we also control for years since immigration in this model, the effect of work experience on occupational status (or income) measures the effect of origin-country work experience. Thus, in terms of occupational attainment, immigrants are better off when they arrive to the host-country after they finish schooling rather than to have worked in origin. In their study of immigrants in the United States, Chiswick and Miller (2009) also found that work experience acquired in the country of origin negatively impacted occupational status but positively affected immigrants' earnings.

Contrary to our hypothesis, we do not find any evidence for a positive interaction between co-ethnic regional concentration and origin-country schooling (Model 3, Tables 2 and 3). That is, the positive effect of education abroad on occupational status and annual income does not differ substantially between regions with high co-ethnic concentration and regions with low co-ethnic concentration.

We also hypothesized that a higher co-ethnic concentration in the region of residence would yield lower economic returns to German human capital (H4). With regards to this hypothesis, our results are mixed. In line with the hypothesis, our results show that the 
positive effect of German education on occupational status and annual income indeed decreases with an increasing percentage of co-ethnics. However, the magnitude of the interaction effect is relatively small. For example, a one-unit standard-deviation increase in co-ethnic concentration decreases the positive effect of German education by only 0.29 status points (from 0.45 to 0.16 ). Regarding income, the difference in the impact of German education is even smaller: an increase of one standard deviation point in co-ethnic concentration decreases the positive effect of German education from 1.1 to 0.8 percent.

Contrary to our hypothesis, however, our results also show that the positive effect of German language skills is slightly greater in regions with many co-ethnics as compared to the regions with fewer co-ethnics (Model3, Table 2). Perhaps the immigrants proficient in German are more likely to serve as translators in the labor market whenever there are more co-ethnics. Because speaking German and having German education tended to be positively correlated, we performed the analysis in Model 3 again, this time separating the two interaction terms. The results, available upon request, show that although the negative effect on occupation and income of the interaction between co-ethnic concentration and German education does not change, the positive interaction between co-ethnic concentration and German language skills is no longer significant. ${ }^{11}$

Additional insights are gained through an examination of the control variables. Our results show a positive effect of weekly working hours on both occupational status and annual income. Doctor visits, an indicator of health status, are associated with lower occupational status, but they have no significant effect on annual income. Occupational status and annual income increase the longer an immigrant has lived in Germany. Finally, our results show that even after accounting for the differences in immigrants' social contacts, duration in Germany, and origin- and destination-country human capital, Turkish immigrants have significantly lower occupational status, but not income, than do Greek and Eastern 
European immigrants. ${ }^{12}$ We found no significant cohort differences in occupational status and annual income of immigrants from including three dichotomous variables for immigrant cohorts.

\section{TABLE 4 ABOUT HERE}

Table 4 presents the results for three sheaf coefficients, i.e., general social contacts, bridging social contacts and host-country human capital on the occupational status and annual income. The results confirm the conclusions from the previous analyses using multiple indicators of social contacts and host-country human capital. Specifically, Table 4 clearly shows that general social contacts increase the annual income, but have insignificant effect on the occupational status of immigrants. Bridging contacts with Germans are much more important for immigrants' occupational status than general social contacts, but both types of social contacts seem to be equally important for the annual income. Thus, when all indicators of bridging contacts are combined immigrants benefit from contact with Germans also regarding annual income. Finally, the results clearly show that the effect of host-country human capital on immigrants' annual income and occupational status is about two and three times stronger, respectively than the effect of both general social contacts and bridging contacts taken together.

\section{Conclusions and discussion}

Using data on adult (age 20 to 60) male immigrants from the German Socio-Economic Panel, we examined the impact of social contacts on the occupational status and annual income of immigrants. Previous studies on the economic integration of immigrant workers have predominantly, or even exclusively, focused on contacts with co-ethnics. Little attention has 
been given to contacts with natives. Furthermore, previous studies relied on cross-sectional data, making it impossible to test for the causal direction of social contacts. The strength of our research design lies in the use of panel data on immigrant social contacts, in particular, contacts with natives, which enables us to examine the causal effect of social contacts. Specifically, we examine whether a positive correlation between social contacts and immigrants' economic outcomes could be explained by reverse causality and spuriousness due to the accumulation of host-country human capital. In addition, we provide further insights into a relationship between social contacts and the economic outcomes of immigrants by studying the interactions between co-ethnic regional concentration and human capital.

Our results confirm the hypothesis that the more social contacts immigrants have, the better their economic outcomes (H1). There is evidence that immigrants who had a German partner and who volunteered during the previous year have marginally higher occupational status than do those who were single and who did not participate in volunteering. Similarly, we find that having a partner and frequent contacts with family, friends and neighbors lead to an increase in subsequent income. The positive effects of general social contacts on immigrant occupational status and, in particular, annual income remain significant even when we take into account the possibility of reverse causality and measure immigrant social contacts up to five years prior to the assessment of occupational status and income.

There is also evidence for the hypothesis that bridging social contacts increase the occupational status and annual income of immigrants (H2). Having a German partner as opposed to an ethnic partner and frequent contacts with Germans lead to an increase in the occupational status, and this relationship remains valid even after we measure the variables up to five years before the occupational status and take into account earlier investments in host-country human capital. The model with sheaf coefficients suggests that having contacts with Germans has a positive impact on immigrants' annual income as well. This means that 
the economic benefits from bridging social capital, in particular, when concerning the occupational status cannot be attributed to a reverse causality or post-migration human capital accumulation. Rather, immigrants may indeed benefit from contact with natives because of the information and influence they provide.

Thus, it appears that there are different effects of social contacts on different economic outcomes. Immigrants benefit from having a partner and contacts with (predominantly coethnic) family, friends and neighbors, which help them find well-paid jobs. However, to the extent these well-paid jobs where immigrants find employment are dangerous, dirty, and degrading jobs (so called “3Ds” jobs) which natives are reluctant to perform, and higher status jobs would be more desirable, immigrants are better off when having contacts with natives. This finding is in line with other studies suggesting the importance of co-ethnic contacts in securing immigrants' employment, and sometimes income, but their limited ability to access high-status jobs (e.g., Wiley 1967; Catanzarite and Aguilera 2002).

Our results also show that, at least in Germany, co-ethnic regional concentration has no significant effect on immigrants’ occupational status and annual income. It is possible that Germany simply lacks substantial ethnic concentrations, like the Cubans in Miami or the Chinese in San Francisco, that significantly influence immigrants' economic outcomes. For example, it could be that the occupational status and income of immigrants are only affected by ethnic concentration if it exceeds certain thresholds values (Tolnay 2001). This could also explain why we do not find evidence for the hypothesized positive interaction on labor market outcomes we expected to see between co-ethnic concentration in the region of residence and origin-country schooling (H3). Moreover, this might also explain only partial confirmation of the hypothesized negative interaction effects between co-ethnic concentration and host-country human capital (H4). 
Alternatively, the insignificant effect of co-ethnic concentration could be explained by the opposing effects of selection of immigrants in the regions with high co-ethnic concentration (Bauer et al. 2005) and co-ethnic concentration on labor market outcomes (Catanzarite and Aguilera 2002). For example, in their study on Latino immigrants in the United States, Chavez et al. (2008) showed that ethnic concentration initially facilitates immigrants' wages by enabling them to communicate in their native language and providing assistance in the host-country labor market, in the long run, however, co-ethnic concentration seemed to reduce immigrants’ opportunities for gainful employment.

Given a small number of recent immigrants in our sample, it is difficult to substantiate any speculations concerning the insignificant effects of co-ethnic concentration in the region of residence and small interaction effects between ethnic concentration and origin-and hostcountry human capital (Catanzarite and Aguilera 2002; Huffman and Cohen 2004). This could be examined more effectively through data on more recent immigrants, who are still in the process of acquiring bridging social capital and host-country human capital.

Most of the previous research highlights the short-term benefits of co-ethnic family and friends in immigrant economic integration (Aguilera and Massey 2003; Portes and Sensenbrenner 1993). In this study, we also show that even immigrants who have already lived in the host-country for an extended period of time benefit from social contacts. Future research could analyze whether and how the effects of social contact change over time. Previous literature suggests that co-ethnic social contacts are most critical for immigrants upon arrival to the host-country, when they lack host-country language skills and credentials (Sanders et al. 2002). However, the importance of social contacts may also increase with the time spent in the host-country, when immigrants acquire better and more resourceful contact with co-ethnics and natives (Hagan 1998). 
Migration studies could also benefit from more detailed measures of bonding and bridging social contacts. This would enable the examination of the exact mechanisms (i.e., number, diversity, resources) for the positive effect of social contacts. For example, although we assume that immigrants benefit from bridging contacts with Germans because of superior information and recommendations to prospective employers provided by such contacts, immigrants with greater contacts with Germans may also have more diverse networks. By incorporating a broader and more dynamic view of social contact into future research, we can better understand the impact of bonding and bridging social contacts on the economic integration of immigrants. 


\section{Footnotes}

1 People who were employed for a very short time were excluded from the analyses. These include people who reported an annual income lower than 6,000 Euros (2.4 percent of observations) and those who worked fewer than 16 hours per week (4.2 percent of observations).

2 It should be mentioned that, as with all panel data, the GSOEP survey is subject to sample attrition. The response rate in the first wave in 1984 exceeded 70 percent in both samples B and D. In 2004, the response rate was about 25 percent in sample B and about 45 percent in sample D (Kroh and Spieß 2008). The main causes of attrition were unsuccessful interviews and ineffective tracking of individuals throughout the survey. Attrition was also related to mortality and migratory movements. Special measures were taken to reduce attrition in the subsequent waves. Temporary dropouts or persons who could not be successfully interviewed in a given year were followed until there were two consecutive temporary dropouts of all household members or a final refusal (Haisken-DeNew and Frick 2005).

3 Distribution of years since migration in Germany.

YSM

Number of observations
Percentage of observations

1.58

23.73

48.49

24.93

1.27

\begin{tabular}{lcc} 
More than 35 years & 124 & 1.27 \\
\hline Total & 9,759 & 100.00
\end{tabular}

Source: GSOEP 1984-2004 
4 The co-ethnic concentration measure was computed for each of the immigrant groups under study: Turkish, Greek, ex-Yugoslavian, Italian, Spanish, Eastern European and Third country immigrants.

5 Eleven geographic regions and seven immigrant groups would generate seventy seven communities, but there were no observations in seventeen theoretical communities.

6 We do not estimate the fixed effects model because of little within individual variation over time in the main independent variables in the data used here (Halaby 2004). For instance, only 200 respondents changed the status of their German schooling during the survey. The limited within individual variation over time in the explanatory variables suggests that a reverse causality between social contacts and immigrant economic outcomes is not likely to be a significant problem.

7 We also run additional models with lagged social contacts variables for up to five years (cf. Model 1, Tables 2 and 3). The results (available upon request) show that it would not change our conclusions for occupational status and annual income if social contacts are lagged up to five years, except for the relationship between volunteering and annual income, which becomes positive and significant.

8 Although our theoretical arguments about the spurious effect of social capital are mainly concerned with social contacts with natives, we included all indicators of social contacts in the models. This is because of the lack of information about the composition of the variables for frequency of social contacts and volunteering, which may involve both co-ethnic and German contacts.

9 We also tested whether the effect of ethnic concentration in the region of residence on the occupational status and annual income was nonlinear by including three dichotomous variables for ethnic concentration. Nevertheless, this is not the case. 
10 Contrary to what one would expect, the economic returns to origin-country schooling are slightly larger (occupational status) or the same (annual income) than the returns to host-country schooling. A possible explanation for this finding is that a very small proportion of immigrants (15.8 percent) invested in additional (secondary or tertiary) education in Germany, which might have had a substantial economic payoff.

11 We also tested whether the effect of co-ethnic concentration in the region of residence varied by immigrants' length of stay in Germany, but this is not the case.

12 We also checked whether there are interethnic differences in the effect of social contacts on immigrants' occupational status and income. The results indicate that all immigrant groups benefit economically from having social contacts, although different types and sources of social contacts are important among immigrant groups. For all, but Third country immigrants, having a German or a co-ethnic partner has a positive effect on the occupational status or income. Similarly, having general social contacts (i.e., frequent contacts with relatives, friends and neighbors, volunteering activity) is beneficial for all but Eastern European and ex-Yugoslavian immigrants. However, the presumed positive effect from having contacts with Germans is less clear. Specifically, only Italians and ex-Yugoslavians benefit economically from having German friends. Finally, living in regions with high concentrations of coethnics does not affect the economic outcomes of all, but East European and Spanish immigrants, for whom co-ethnic concentration has a detrimental effect on the economic outcomes. 


\section{References}

Aguilera, M. B. 2002 “The impact of social capital on labor force participation: evidence from the 2000 social capital benchmark survey.” Social Science Quarterly 83(3): 853-74.

Aguilera, M. B. 2003 "The impact of the worker: how social capital and human capital influence the job tenure of formerly undocumented Mexican immigrants.” Sociological Inquiry 73(1):52-83.

Aguilera, M. B. 2005 “The impact of social capital on the earnings of Puerto Rican migrants.” The Sociological Quarterly 46(4):569-92.

Aguilera, M. B., and D. S. Massey 2003 “Social capital and the wages of Mexican migrants: new hypotheses and tests.” Social Forces 82(2):671-701.

Aiken, L. S., and S. G. West. 1991. Multiple Regression: Testing and Interpreting Interactions. Sage Publications.

Amuedo-Dorantes C., and K. Mundra 2008 "Social Networks and their Impact on the Earnings of Mexican Migrants.” Demography 44(4):849-63.

Bauer, T., G. Epstein, and I. Gang. 2005 "Enclaves, language, and the location choice of migrants.” Journal of Population Economics 18(4):649-62.

Becker, G. S. 2007 "Health as human capital: synthesis and extensions.” Oxford Economic Papers 59(3): 379-410.

Bratsberg, B., and J. F. Ragan 2002 "The impact of host country schooling on earnings. a study of male immigrants in the United States." The Journal of Human Resources 37(2):64-105. 
Boxman, A. W., P. M., De Graaf, and H. D. Flap 1991 “The impact of social and human capital on the income attainment of Dutch managers.” Social Networks 13(1):51-73.

Buis, M. 2009. “Three models for combining information from causal indicators,” United Kingdom Stata Users' Group Meetings 2009 03, Stata Users Group.

Burt, R. S. 2000. "Structural holes versus network closure as social capital.” Preprint of a chapter in Social Capital: Theory and Research. Ed. N. Lin, K. Cook, and R. S. Burt. New York: Aldine De Gruyter (available via the homepage of R. S. Burt).

Catanzarite, L., and M. B. Aguilera 2002. "Working with Co-Ethnics: Earnings Penalties for Latino Immigrants at Latino Jobsites.” Social Problems 49(1):101-27.

Chavez, S., T. Mouw, and J. Hagan. 2008. “Occupational Enclaves and the Wage Growth of Hispanic Immigrants.” Paper presented at the annual meeting of the American Sociological Association, Boston, August 2008 (copy available from the authors).

Chiswick, B. R. 1978. "The Effect of Americanization on the Earnings of Foreign-born Men.” Journal of Political Economy 86(5):897-921.

Chiswick, B. R., and P. W. Miller 1995 “The Endogeneity between language and earnings: international analyses.” Journal of Labor Economics 13(2):246-88.

Chiswick, B. R., and P. W. Miller 2002 "Immigrant earnings: language skills, linguistic concentrations and the business cycle.” Journal of Population Economics 15(1):31-57.

Chiswick, B. R., and P. W. Miller 2005 “Do Enclaves Matter in Immigrant Adjustment.” City \& Community 4(1):5-35.

Chiswick, B. R., and P. W. Miller 2009 “Earnings and Occupational Attainment Among Immigrants.” Industrial Relations: A Journal of Economy and Society, 48(3): 454-65. 
De Graaf, N. D., and H. D. Flap 1988 “With a little help from my friends: social resources as an explanation of occupational status and income in West Germany, the Netherlands, and the United States.” Social Forces 67(2):452-72.

Drever, A. I. and O. Hoffmeister 2008 "Immigrants and social networks in a job-scarce environment: the case of Germany.” International Migration Review 42(2):425-48.

Duleep, H. O., and M. C. Regets 1997 “The Decline in Immigrant Entry Earnings: Less Transferable Skills or Lower Ability?” Quarterly Review of Economics and Finance 37:189-208.

Duleep, H. O., and M. C. Regets 1999 “Immigrants and Human-Capital Investment.” American Economic Review 89(2):186-90.

Dustmann C., and A. V. Soest 2002 “Language and the earnings of immigrants.” Industrial and Labor Relations Review 55(3):473-92.

Fernandez-Kelly, M. P. 1995 "Social and cultural capital in the urban ghetto: implications for the economic sociology of immigration.” In The Economic Sociology of Immigration: Essays on Networks, Ethnicity and Entrepreneurship. Ed. A. Portes. New York: Russell Sage Foundation. Pp. 213-47.

Friedberg, R. M. 2000 "You can't take it with you? Immigrant assimilation and the portability of human capital.” Journal of Labor Economics 18(2):221-51.

Froot, K. A. 1989. “Consistent covariance matrix estimation with cross-sectional dependence and heteroskedasticity in financial data.” Journal of Financial and Quantitative Analysis 24: 333-355. 
Fong, E., and E. Ooka 2002 "The Social Consequences of Participating in the Ethnic Economy.” International Migration Review 36(1):125-146.

Ganzeboom, H. B. G., and D. J. Treiman. 1996 “Internationally Comparable Measures of Occupational Status for the 1988 International Standard Classification of Occupations.” Social Science Research 25:201-39.

Ganzeboom, Harry B. G., P. M. De Graaf, and D. J. Treiman. 1992. “A Standard International Socio-Economic Index of Occupational Status.” Social Science Research 21(1):1-56.

Granovetter, M. 1973 “The strength of weak ties.” American Journal of Sociology 78(6):1360-80.

Hagan, J. M. 1998 “Social Networks, Gender and Immigrant Settlement: Resource and. Constraint.” American Sociological Review 63(1):55-67

Halaby, Ch. N. 2004 “Panel Models in Sociological Research: Theory into Practice.” Annual Review of Sociology 30:507-44.

Haisken-DeNew J. P., and J. R. Frick 2005 “Desktop Companion to the German SocioEconomic Panel (DTC).” Berlin: German Institute for Economic Research (DIW).

Heckman, J. 1979 “Sample Selection Bias as a Specification Error.” Econometrica 47:15362.

Ioannides, Y. M., and L. D. Loury 2004 “Job information networks, neighborhood effects, and inequality.” Journal of Economic Literature 42(4):1056-93.

Kalter, F. 2006 “Auf Suche nach einer Erklärung für die spezifischen Arbeitsmarktnachteile von Jugendlichen türkischer Herkunft.“ Zeitschrift für Soziologie 35:144-60. 
Kanas, A., and F. van Tubergen 2009 "The Impact of Origin and Host Country Schooling on the Economic Performance of Immigrants.” Social Forces 88(2):893-916..

Kanas, A., F. van Tubergen, and T. van der Lippe 2009 "Immigrant Self-Employment: Testing Hypotheses About the Role of Origin- and Host-Country Human Capital and Bonding and Bridging Social Capital.” Work and Occupations 36(3):181-208.

Kanas, A., F. Van Tubergen, and T. Van der Lippe Forthcoming "The Role of Social Contacts in the Employment Status of Immigrants: A Panel Study of Immigrants in Germany.” International Sociology.

Kazemipur, A. 2006 “The market value of friendship: social networks of immigrants.” Canadian Ethnic Studies Journal 38(2):47-71.

Kogan, I., and F. Kalter 2006 "The Effects of Relative Group Size on Occupational Outcomes: Turks and Ex-Yugoslavs in Austria.” European Sociological Review 22(1):3548.

Kroh, M., and M. Spieß 2008 "Documentation of Sample Sizes and Panel Attrition in the German Socio Economic Panel (SOEP) (1984 until 2007).” Berlin: German Institute for Economic Research (DIW).

Lancee, B. 2010 “The economic returns of immigrants’ bonding and bridging social capital. The case of the Netherlands.” International Migration Review 44(1):202-26.

Lin, N., W. M. Ensel, and J. C . Vaughn 1981 "Social Resources and Strength of Ties: Structural Factors in Occupational Status Attainment.” American Sociological Review 46(4):393-405.

Lin, N. 1999 “Social networks and status attainment.” Annual Review of Sociology 25:46787. 
Lin, N. 2000 “Inequality in Social capital.” Contemporary Sociology 29(6):785-95.

Martinovic, B., F. van Tubergen, and I. Maas 2009 "Dynamics of Interethnic Contact: A Panel Study of Immigrants in the Netherlands.” European Sociological Review 25(3):303-18.

McPherson, M., L. Smith-Lovin, and J. M. Cook 2001 "Birds of feather: Homophily in Social Networks.” Annual review of Sociology 27: 415-44.

Mesch, G. S. 2002. "Between Spatial and Social Segregation among Immigrants: The Case of Immigrants from the FSU in Israel.” International Migration Review 36(3):912-34.

Microcensus Scientific Use File. 2009 "Special analysis of the German Microdata Lab.” Mannheim: GESIS.

Mouw, T. 2002 "Racial differences in the effects of job contacts: conflicting evidence from cross-sectional and longitudinal data.” Social Science Research 31(4):511-38.

Mouw, T. 2003 “Social capital and finding a job: do contacts matter?” American Sociological Review 68(6): 868-98.

Mouw, T. 2006 "Estimating the Causal Effect of Social Capital: A Review of Recent Research” Annual Review of Sociology 32:79-102

Nee, V., J. M. Sanders, and S. Sernau 1994 “Job transition in an immigrant metropolis: ethnic boundaries and the mixed economy.” American Sociological Review 59(6):849-72.

OECD. 2008. International Migration Outlook. Paris: Organisation for Economic Cooperation and Development.

Pischke J. S. 1992 “Assimilation and the earnings of guestworkers in Germany.” Mannheim: ZEW Discussion Paper no 92-17. 
Portes, A. 1998 “Social Capital: Its Origins and Applications in Modern Sociology.” Annual Review of Sociology 24:1-24.

Portes, A., and L. Jensen 1989 "The enclave and the entrants: Patterns of ethnic enterprise in Miami before and after Mariel.” American Sociological Review 54(6):929-49.

Portes, A. and J. Sensenbrenner 1993 "Embeddedness and immigration: notes on the social determinants of economic action.” American Journal of Sociology 98(6):1320-50.

Putnam, R. D. 2000 Bowling Alone: The Collapse and Revival of American Community. New York: Simon \& Schuster.

Sanders, J. M., and V. Nee 1987 "Limits of Ethnic. Solidarity in the Enclave Economy." American Sociological Review 52:745-73.

Sanders, J. M., V. Nee, and S. Sernau 2002 “Asian immigrants’ reliance on social ties in a multiethnic labor market.” Social Forces 81(1):281-314.

Shields M. A. and S. Wheatley Price 2002 "The English language fluency and occupational success of ethnic minority immigrant men living in English metropolitan areas.” Journal of Population Economics 15(1):137-60.

Sloane, P. J. 1985. “Discrimination in the Labour Market.” In Surveys in Labour Economics. Eds. D. Carline, C.A. Pissarides, W. Siebert and J. Sloane. Longman Group Limited, Essex, England.

South, S. J., K. Crowder, and E. Chavez 2005 “Geographic Mobility and Spatial Assimilation among U. S. Latino Immigrants.” International Migration Review 39(3): 577-607.

Stata Library. 2010 “Analyzing Correlated (Clustered) Data.” Available at <http://www.ats.ucla.edu/stat/stata/library/cpsu.htm> Accessed on May 172010. 
Whitt, H. P. 1986. “The Sheaf Coefficient: A Simplified and Expanded Approach.” Social Science Research 15(2):174-89.

Wiley, N. F. 1967 “The Ethnic Mobility Trap and Stratification Theory.” Social Problems $15: 147-59$.

Yamaguchi, K. 2002. "Regression models with parametrically weighted explanatory variables.” Sociological Methodology 32: 219-245. 
Table 1 Descriptive Statistics of Independent and Dependent Variables

\begin{tabular}{|c|c|c|c|}
\hline & Range & Mean & S.D. \\
\hline \multicolumn{4}{|l|}{ Dependent variables } \\
\hline Occupational status (ISEI) & $16-88$ & 32.92 & 9.60 \\
\hline Annual Income (ln) & $8.70-12.53$ & 10.06 & 0.35 \\
\hline \multicolumn{4}{|l|}{ Independent variables } \\
\hline \multicolumn{4}{|l|}{ Social capital } \\
\hline Frequency of contacts $\mathrm{t}-1$ & $1-3$ & 2.86 & 0.41 \\
\hline Volunteering activity t-1 & $0 / 1$ & 0.15 & \\
\hline Contacts with Germans t-1 & $0-1$ & 0.84 & 0.30 \\
\hline Ethnic concentration t-1 & $0.06-7.55$ & 2.24 & 1.71 \\
\hline Partner & $0 / 1$ & 0.76 & \\
\hline \multicolumn{4}{|l|}{ Ethnic t-1 } \\
\hline German t-1 & $0 / 1$ & 0.09 & \\
\hline Single t-1 & $0 / 1$ & 0.15 & \\
\hline \multicolumn{4}{|l|}{ Human capital } \\
\hline Education abroad (years) & $0-17$ & 8.11 & 3.61 \\
\hline Education in Germany (years) $\mathrm{t}-2$ & $0-18$ & 3.23 & 5.05 \\
\hline German language skills t-2 & $1-4$ & 2.63 & 0.88 \\
\hline Years of work experience $t-2$ & $0-47$ & 18.53 & 10.55 \\
\hline \multicolumn{4}{|l|}{ Control variables } \\
\hline Years since migration & $2-42$ & 20.52 & 7.35 \\
\hline Weekly working hours & $16-70$ & 41.86 & 7.20 \\
\hline Doctor visits & $0 / 1$ & 0.55 & \\
\hline \multicolumn{4}{|l|}{ Immigrant group } \\
\hline Turkish & $0 / 1$ & 0.35 & \\
\hline Greek & $0 / 1$ & 0.11 & \\
\hline Yugoslavian & $0 / 1$ & 0.12 & \\
\hline Italian & $0 / 1$ & 0.18 & \\
\hline Spanish & $0 / 1$ & 0.08 & \\
\hline Eastern European & $0 / 1$ & 0.06 & \\
\hline Third country & $0 / 1$ & 0.10 & \\
\hline
\end{tabular}

Source: GSOEP 1984-2004.

Note: Descriptive statistics for survey year not presented.

Number of observations: 9,759.

Number of individuals: 1,393 
Table 2 Heckman Selection Model of Immigrants' Occupational Status

\begin{tabular}{|c|c|c|c|c|c|c|}
\hline & \multicolumn{2}{|l|}{ Model 1} & \multicolumn{2}{|l|}{ Model 2} & \multicolumn{2}{|l|}{ Model 3* } \\
\hline & $\mathrm{B}$ & S.E. & $\mathrm{B}$ & S.E. & $\mathrm{B}$ & S.E. \\
\hline \multicolumn{7}{|l|}{ Independent variables } \\
\hline \multicolumn{7}{|l|}{ Social capital } \\
\hline Frequency of contacts t- 1 & 0.383 & 0.399 & 0.038 & 0.373 & -0.090 & 0.363 \\
\hline Volunteering activity t-1 & $1.391 * *$ & 0.364 & 0.599 & 0.313 & $0.670 *$ & 0.320 \\
\hline Contacts with Germans t- 1 & $2.936 * *$ & 0.557 & $1.100 *$ & 0.529 & $1.197 *$ & 0.515 \\
\hline \multicolumn{7}{|l|}{ Partner (ref. Ethnic) } \\
\hline German t-1 & $4.285 *$ & 1.425 & $2.613^{*}$ & 1.303 & $2.433^{*}$ & 1.164 \\
\hline Single t-1 & 0.587 & 0.549 & -0.876 & 0.473 & $-0.996^{*}$ & 0.434 \\
\hline Ethnic concentration (\%) t-1 & 0.112 & 0.187 & 0.104 & 0.180 & 0.087 & 0.189 \\
\hline \multicolumn{7}{|l|}{ Human capital } \\
\hline Education abroad (years) & & & $0.718 * *$ & 0.098 & $0.682 * *$ & 0.089 \\
\hline Education in Germany (years) t-2 & & & $0.479 * *$ & 0.107 & $0.453^{* *}$ & 0.070 \\
\hline German language skills t-2 & & & $1.462 * *$ & 0.259 & $1.553^{* *}$ & 0.205 \\
\hline Work experience t-2 & & & $-0.223^{*}$ & 0.072 & $-0.241 * *$ & 0.065 \\
\hline Work experience squared t-2 & & & $0.003^{*}$ & 0.001 & $0.004 *$ & 0.001 \\
\hline \multicolumn{7}{|l|}{ Control variables } \\
\hline Years since migration & $0.101^{*}$ & 0.045 & $0.188 * *$ & 0.050 & $0.176 * *$ & 0.048 \\
\hline Weekly working hours & $0.185^{* *}$ & 0.035 & $0.156^{*}$ & 0.050 & $0.152 * *$ & 0.033 \\
\hline Doctor visits (ref. No visits) & $-0.695 *$ & 0.278 & $-0.528 *$ & 0.245 & $-0.559 *$ & 0.232 \\
\hline \multicolumn{7}{|l|}{ Immigrant group (ref. Turkish) } \\
\hline Greek & $3.956 * *$ & 0.870 & $3.885 * *$ & 0.732 & $3.529 * *$ & 0.657 \\
\hline Yugoslavian & 0.307 & 0.693 & 0.439 & 0.650 & 0.187 & 0.546 \\
\hline Italian & -0.338 & 0.730 & 0.520 & 0.654 & 0.310 & 0.621 \\
\hline Spanish & 0.869 & 1.123 & 1.560 & 0.883 & 1.279 & 0.811 \\
\hline Eastern European & $5.007 *$ & 1.571 & $3.885^{*}$ & 1.410 & $3.414^{*}$ & 1.375 \\
\hline Third country & 0.840 & 0.893 & 0.604 & 0.692 & 0.320 & 0.658 \\
\hline \multicolumn{7}{|l|}{ Interactions } \\
\hline Ethnic concentration (\%) t- $1 *$ Educ abroa & & & & & -0.073 & 0.045 \\
\hline Ethnic concentration (\%) $\mathrm{t}-1 *$ Educ in & & & & & $-0.174 * *$ & 0.034 \\
\hline Germany t-2 & & & & & & \\
\hline $\begin{array}{l}\text { Ethnic concentration (\%) } \mathrm{t}-1 * \text { German } \\
\text { language skills } \mathrm{t}-2\end{array}$ & & & & & $0.311 *$ & 0.118 \\
\hline Constant & $18.26 * *$ & 2.400 & $12.63 * *$ & 3.166 & $25.03 * *$ & 1.839 \\
\hline Number of observations & 9759 & & 9759 & & 9759 & \\
\hline Number of clusters & 60 & & 60 & & 60 & \\
\hline Number of individuals & 1393 & & 1393 & & 1393 & \\
\hline
\end{tabular}

Source: GSOEP 1984-2004.

Unstandardized coefficients; ${ }^{* *} \mathrm{p}<.001 ; \quad{ }^{*} \mathrm{p} \leq .05$ (two-sided test).

The model also includes a set of dummy variables for survey year.

*The continuous variables of Education abroad, Education in Germany, German language skills, and Ethnic concentration are mean-centered. 
Table 3 Heckman Selection Model of Immigrants’ Annual Income

\begin{tabular}{|c|c|c|c|c|c|c|}
\hline & \multicolumn{2}{|l|}{ Model 1} & \multicolumn{2}{|l|}{ Model 2} & \multicolumn{2}{|l|}{ Model 3* } \\
\hline & $\mathrm{B}$ & S.E. & $\mathrm{B}$ & S.E. & $\mathrm{B}$ & S.E. \\
\hline \multicolumn{7}{|l|}{ Independent variables } \\
\hline \multicolumn{7}{|l|}{ Social capital } \\
\hline Frequency of contacts t- 1 & $0.050 * *$ & 0.012 & $0.047 * *$ & 0.011 & $0.045^{* *}$ & 0.011 \\
\hline Volunteering activity t-1 & 0.019 & 0.012 & 0.010 & 0.012 & 0.011 & 0.012 \\
\hline Contacts with Germans t- 1 & 0.032 & 0.018 & 0.002 & 0.017 & 0.003 & 0.017 \\
\hline \multicolumn{7}{|l|}{ Partner (ref. Ethnic) } \\
\hline German t-1 & 0.055 & 0.028 & 0.043 & 0.024 & 0.041 & 0.025 \\
\hline Single t-1 & $-0.078 * *$ & 0.020 & $-0.063^{* *}$ & 0.017 & $-0.064 * *$ & 0.017 \\
\hline Ethnic concentration (\%) t-1 & -0.001 & 0.011 & 0.0001 & 0.010 & -0.0003 & 0.010 \\
\hline \multicolumn{7}{|l|}{ Human capital } \\
\hline Education abroad (years) & & & $0.013^{* *}$ & 0.003 & $0.012 * *$ & 0.003 \\
\hline Education in Germany (years) t-2 & & & $0.012 * *$ & 0.002 & $0.011 * *$ & 0.002 \\
\hline German language skills t-2 & & & $0.031 * *$ & 0.009 & $0.032 * *$ & 0.009 \\
\hline Work experience t-2 & & & $0.014 * *$ & 0.003 & $0.014^{* *}$ & 0.003 \\
\hline Work experience squared t-2 & & & $-0.0003 * *$ & 0.000 & $-0.0003 * *$ & 0.000 \\
\hline \multicolumn{7}{|l|}{ Control variables } \\
\hline Years since migration & $0.009 * *$ & 0.001 & $0.006^{* *}$ & 0.002 & $0.006 * *$ & 0.002 \\
\hline Weekly working hours & $0.005 * *$ & 0.001 & $0.004 * *$ & 0.001 & $0.004 * *$ & 0.001 \\
\hline Doctor visits (ref. No visits) & 0.008 & 0.009 & 0.008 & 0.009 & 0.007 & 0.008 \\
\hline \multicolumn{7}{|l|}{ Immigrant group (ref. Turkish) } \\
\hline Greek & 0.011 & 0.054 & 0.008 & 0.053 & 0.004 & 0.053 \\
\hline Yugoslavian & 0.035 & 0.031 & 0.018 & 0.031 & 0.015 & 0.031 \\
\hline Italian & -0.040 & 0.044 & -0.032 & 0.044 & -0.035 & 0.043 \\
\hline Spanish & 0.006 & 0.051 & 0.003 & 0.051 & 0.0003 & 0.051 \\
\hline Eastern European & 0.091 & 0.050 & 0.025 & 0.047 & 0.018 & 0.048 \\
\hline Third country & 0.032 & 0.040 & 0.011 & 0.039 & 0.007 & 0.039 \\
\hline \multicolumn{7}{|l|}{ Interactions } \\
\hline Ethnic concentration (\%) t- $1 *$ Educ abroa & & & & & -0.001 & 0.001 \\
\hline Ethnic concentration (\%) t- $1 *$ Educ in & & & & & $-0.002 *$ & 0.001 \\
\hline \multicolumn{7}{|l|}{ Germany t-2 } \\
\hline $\begin{array}{l}\text { Ethnic concentration (\%) t- } 1 * \text { German } \\
\text { language skills } \mathrm{t}-2\end{array}$ & & & & & 0.003 & 0.005 \\
\hline Constant & $9.284 * *$ & 0.081 & $9.041 * *$ & 0.086 & $9.268 * *$ & 0.070 \\
\hline Number of observations & 9759 & & 9759 & & 9759 & \\
\hline Number of clusters & 60 & & 60 & & 60 & \\
\hline Number of individuals & 1393 & & 1393 & & 1393 & \\
\hline
\end{tabular}

Source: GSOEP 1984-2004.

Unstandardized coefficients; ${ }^{* *} \mathrm{p}<.001 ; \quad{ }^{*} \mathrm{p} \leq .05$ (two-sided test).

The model also includes a set of dummy variables for survey year.

* The continuous variables of Education abroad, Education in Germany, German language skills, and Ethnic concentration are mean-centered. 
Table 4 Heckman Selection Model of Immigrants' Occupational Status and Annual Income using Sheaf Coefficients

\begin{tabular}{llllc}
\hline & \multicolumn{2}{c}{ Occupational status } & Annual Income \\
\cline { 2 - 5 } & \multicolumn{2}{c}{ B } & S.E. & B \\
\hline Sheaf coefficients & \multicolumn{3}{c}{ S.E. } \\
General social contacts & 0.219 & 0.117 & $0.02^{* *}$ & 0.005 \\
Bridging social contacts & $0.855^{*}$ & 0.312 & $0.02^{* *}$ & 0.005 \\
Host-country human capital & $3.129^{* *}$ & 0.464 & $0.07^{* *}$ & 0.010 \\
Constant & $12.63^{* *}$ & 2.862 & $9.01^{* *}$ & 0.084 \\
\hline Number of observations & 9759 & & 9759 & \\
Number of clusters & 60 & & 60 & 1393 \\
Number of individuals & 1393 & & &
\end{tabular}

Source: GSOEP 1984-2004.

Standardized sheaf coefficients; ${ }^{* *} \mathrm{p}<.001 ; \quad * \mathrm{p} \leq .05$ (two-sided test).

The three sheaf coefficients are "general social contacts" comprising of frequency of contacts and volunteering activity; "bridging contacts" comprising of three indicators of German contacts (i.e., having close German friends, being visited by Germans and visiting Germans) and German partner versus single/ethnic partner; and "host-country human capital" comprising of German education and German language skills.

The model also includes: ethnic concentration, education abroad, work experience, work experience squared, years since migration, weekly working hours, doctor visits, immigrant group, and a set of dummy variables for survey year (cf. Model 2, Table 2 and 3). 